\title{
OBSERVATION OF FLOWER VISITORS TO DETERMINE THEIR POTENTIAL ROLE AS POLLINATORS OF Ixora coccinae AND Ruellia simplex
}

\author{
FAKHRIAH KAMARUDDIN ${ }^{\mathrm{A}}$ AND MOHAMED NOR ZALIPAH ${ }^{\mathrm{B} *}$ \\ ${ }^{a, b}$ Faculty of Science and Marine Environment, Universiti Malaysia Terengganu, 21030 Kuala Nerus, Terengganu. \\ *Corresponding author: zalipah@umt.edu.my
}

\begin{abstract}
This study aimed to determine the potential pollinating agents of Ixora coccinae and Ruellia simplex at Universiti Malaysia Terengganu (UMT) campus based on the foraging activities of the flower visitors. The diurnal observations $(0700 \mathrm{hr}$ to $1800 \mathrm{hr})$ were conducted for a total of 144 hours and 96 hours for $I$. coccinae, for $R$. simplex respectively. The flower visitor activities (landing or hovering at the flowers) and the time spent at the flowers however were recorded for only the first 10 minutes of every hour between $0700 \mathrm{hr}$ and $1000 \mathrm{hr}$ for four days. A total of 383 flower visitations was recorded by 17 insect species and a bird species, the olive-backed sunbird (Cinnyris jugularis). For I. coccinae, the most common visitors were Apis cerana, Heterotrigona itama and Xylocopa confusa, in which all species were found to show only landing behaviour to forage at the flowers, and the time spent foraging at the flowers was not significantly different between the species (Kruskal-Wallis test, $H=1.323, \mathrm{df}=2, \mathrm{p}=0.055$ ). For $R$. simplex, the most common visitors were A. cerana with $100 \%$ landing, and $C$. jugularis which recorded $80 \%$ landing and $20 \%$ hovering during their visits to the flowers. Between the two, A. cerana recorded significantly longer time spent at the flowers as compared to $C$. jugularis (Mann-Whitney test, $U=17.355, \mathrm{p}<0.001$ ). Based on the visitation rate and feeding behaviour of the flower visitors, A. cerana, H. itama and X. confusa were the potential pollinating agents for I. coccinae while for $R$. simplex, A. cerana showed higher potential to be a pollinating agent as compared to $C$. jugularis. Therefore, this study highlighted the importance of recording the behaviour of each flower visitor to determine the relative contribution to the pollination success of the plant species visited.
\end{abstract}

Keywords: Apis cerana, C. jugularis, flower visitors, landing, pollinating agents, time spent.

\section{Introduction}

Flower visitors come to flowers to feed on nectar and other flower parts. While feeding on the flowers, flower visitors might contact the stigma and anthers of the flowers and therefore act as pollinating agents by transferring the pollen to the stigma of the flowers for fertilisation. Although pollination could occur by the help of wind, pollen transfer for the majority of tropical flowering plants was conducted by the animals as vector (Stein \& Hansen, 2011; Rech et al., 2016). Further, Regal (1982) showed that pollination by wind is uncommon in tropical rainforest due to the dense structure of the forest which reduces the wind speed. In this mutualistic interaction, both flowering plant species and the animal pollinating agents were benefitted in terms of pollination service and the reward for the animal agents (Glover, 2007; JedrzejewskaSzmek \& Zych, 2013).

Pollination by animals in flowering plants is approximately $87 \%$ worldwide (Ollerton et al., 2011). Pollination by reptiles such as by lizards is more common in the island than in the mainland (Olesen \& Valido, 2003), while pollination by rodents occurs for geoflory flowers, in which flowers are at the ground level (Johnson \& Pauw, 2014). Insects and birds, however, are among the most common pollinating agents. For example, Cronk and Ojeda (2008) stated that birds from Nectariniidae family which are 
spiderhunters and sunbirds are great pollinating agents in Asia and Africa. Insects from the order of Coleoptera, Diptera, Hymenoptera and Lepidoptera are among the most common pollinating agents (Dobson, 2006). The stingless bees (Hymenoptera) for example, are the new effective commercial pollinating agents especially for the crops (Slaa et al., 2006) in which apiary industry has emerged.

The two flowering species selected in this study, I. coccinae and $R$. simplex are among the most cultivated garden and landscape plants in the Asian region. Ixora is a genus from Rubiaceae family with approximately 500 species (De Block, 1998), including many cultivars and hybrids (Rajaseger et al., 1997; Mouly et al., 2009). Ixora coccinae is a native shrub of Southern India, Bangladesh and Sri Lanka, but it is widely planted in other Asian regions for its showy corollas (Mouly et al., 2009). This evergreen shrub can grow up to $3 \mathrm{~m}$ in height and flowers can be found throughout the year. The flowers are small tubular, bright red and are in a dense rounded cluster. There are about 2-5 flowers in a cluster arranged in opposite and articulate axes. The flowers are erect at a terminal position for ease of access by the flower visitors.

Ruellia is also a highly diverse genus from the family of Acanthaceae, with ca. 300 species (Wasshausen \& Wood, 2003). Reullias are popular ornamental plants with various corolla colour from red, yellow and purple, although purple and red are the most common from the anthocyanin's pigments produced by the plants (Bloom, 1976). Ruellia simplex is an evergreen perennial plant which is native to Mexico and South America. The plants are about $1 \mathrm{~m}$ tall and the flowers are trumpet-shaped with purple corollas.

Previous studies reported Lepidoptera (butterflies and moths) as pollinating agents for the genus Ixora (Nilsson et al., 1990; Kato et al., 2008; Duara, 2014), while wide array of insects (butterflies, moths, bees, beetles, hemipteran), birds and event bats (Trip \& Manos, 2008; Faria \& Araujo, 2010; Hawkeswood \& Sommung, 2016) were reported as pollinators of the genus Ruellia. The conclusion of these studies, however, was made from visitation of these insects and vertebrate faunas to the flowers to feed. Feeding behaviour of floral visitors however determines their role as legitimate, effective or efficient pollinators (Fleming \& Sosa, 1994). For example, some floral visitors are only nectar robbers or pollen thieves, in which these floral visitors are only taking pollen and nectar without making contact with the reproductive organs, thus precluding the possibility of pollination occurring (Inouye, 1980). Therefore, in this study, the pollinating agents of Ixora coccinae (jungle geranium) and Ruellia simplex (Mexican bluebell) were determined from the feeding activities (viz. visitation frequencies and time spent at the flowers) of the flower visitors at Universiti Malaysia Terengganu campus, Terengganu.

\section{Materials and Methods}

\section{Study site}

The study was conducted at Universiti Malaysia Terengganu (UMT) campus in the Kuala Nerus District, located $25 \mathrm{~km}$ from the city of Kuala Terengganu. The two flowering plants selected in this study have been planted abundantly on the campus (Figure 1). Observations of $I$. coccinae were conducted behind Bina Syarahan building (5'24'47.49'N, $103^{\circ} 5^{\prime}$ '13.47'E, ) while $R$. simplex was observed in front of the School of Marine and Environmental Sciences building $\left(5^{\circ} 24^{\prime} 42.93^{\prime \prime} \mathrm{N}, 103^{\circ} 5^{\prime} 7.74\right.$ ' E, Figure 2). At the study area, there were nine trees and 50 plants for $I$. coccinae and $R$. simplex respectively. 

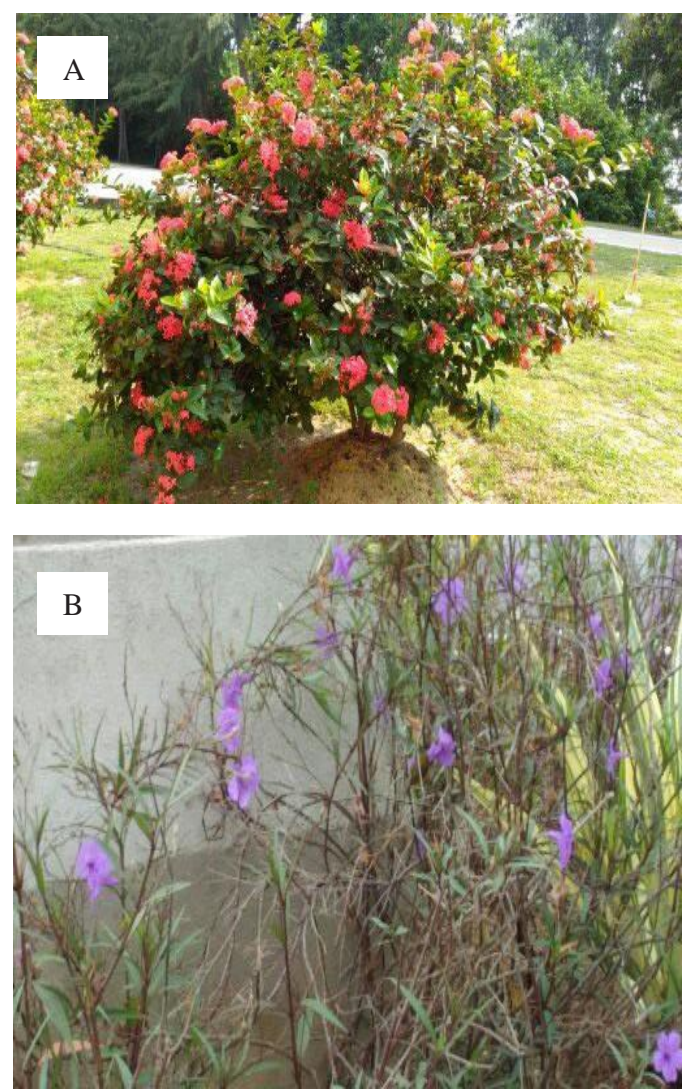

Figure 1: The flowering plants observed in this study: (A) Ixora coccinae and (B) Ruellia simplex

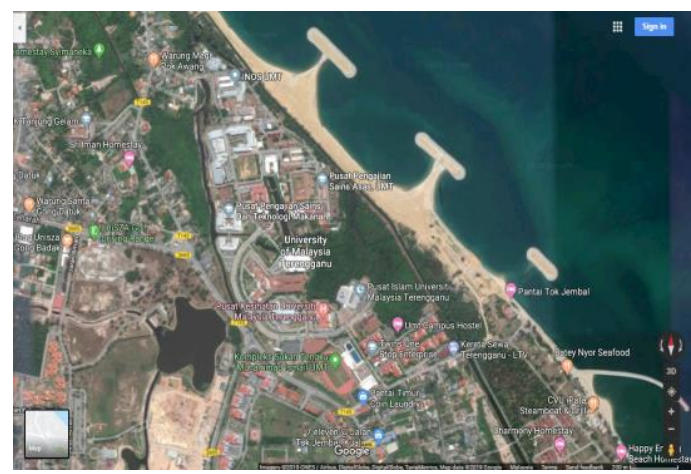

Figure 2: Two sampling sites in Universiti Malaysia Terengganu (UMT) campus. Right circle represents the location of Bina Syarahan building and the left circle is the location of the School of Marine and

Environmental Sciences building

\section{Observations of Flower Visitors}

Observations to document the potential pollinators of the two species were conducted from August to September 2016 and January to February 2017. Direct observations were made by an observer from a distance of approximately $2 \mathrm{~m}$ away from the flowering plants during the sunny days and equipped with a a pair of binoculars (Minox BL 10x44 HD, MINOX, Germany). The diurnal observations were divided into three sessions, namely, morning (0700 hr to $1000 \mathrm{hr}$ ), afternoon (1100 hr to 1400 hr) and evening (1500 hr to $1800 \mathrm{hr}$ ).

For each hour, visitation frequency and foraging behaviour of the flower visitors were noted for only the first 10 minutes. A visit was considered when a flower visitor was at a close distance of the flower, (ca. $1-2 \mathrm{~cm}$ ) from the petals. Visits were recorded irrespective to previous visits by the flower visitors to the focal flower. The visitation frequency for each plant species was conducted for a total of 144 hours and 96 hours for $I$. coccinae and $R$. simplex respectively.

For the most common visitors to the flowers of each plant species, foraging activities of the flower visitors were further observed by focal sampling, and only recorded from $0700 \mathrm{hr}$ to $1000 \mathrm{hr}$ each morning for four days. The foraging behaviour of the flower visitors was recorded as either hovering or landing on flowers, and the time spent at the flower was recorded using digital stopwatch starting from when the visitor first approached the flower (ca 1-2cm distance from the flower) until it flew away. Insect samplings were further administered after the observations for identification using hand-held insect net. The insects were then identified by referring to the available insect collection from Herbarium and Insectarium of Central Laboratory, UMT. All statistical analyses were conducted in IBM SPSS Statistics v25.0 (Chicago, USA). 


\section{Results and Discussion}

In this study, a total of 383 flower visitations by the insects (17 species) were recorded as compared to only a single species of bird, the olive-backed sunbird, Cinnyris jugularis (Table 1). From this, 276 visits to $I$. coccinae flowers were recorded and 107 visitations were made to $R$. simplex flowers. The most frequent visitor to the flowers was Apis cerana (Asian honey bee), with 0.63 visits/hr and $1.00 \mathrm{visit} / \mathrm{hr}$ to $I$. coccinae and $R$. simplex respectively. For both plant species, the predominant visitors were insects, as compared to only one species of sunbird recorded visiting the flowers. Ixora coccinae was visited by a wide range of insect species, mainly the hymenopterans (eight species) and hemipterans (five species), as compared to only three insect species visiting $R$. simplex.

Table 1: List of flower visitors and their visitation frequency (visit/hr) to the flowers. Numbers in parentheses indicate number of visits (in \%) recorded by each flower visitor observed in the first 10 minutes of every observation hour

\begin{tabular}{|c|c|c|c|c|}
\hline Order & Famili & Species & Ixora coccinae & Ruellia simplex \\
\hline \multirow[t]{8}{*}{ Hymenoptera } & \multirow[t]{6}{*}{ Apidae } & Apis cerana & $0.63^{@}(33.0)$ & $1.00^{\&}(87.9)$ \\
\hline & & Apis florea & $0.02(1.1)$ & - \\
\hline & & Apis dorsata & $0.10(5.4)$ & - \\
\hline & & Heterotrigona itama & $0.57^{\circledR}(29.7)$ & - \\
\hline & & Xylocopa confusa & $0.26^{@}(13.4)$ & - \\
\hline & & Xylocopa violacea & $0.03(1.8)$ & - \\
\hline & \multirow[t]{2}{*}{ Vespidae } & Vespa tropica & $6.94 \times 10^{-3}(0.4)$ & - \\
\hline & & Unidentified sp. 1 & $0.04(2.2)$ & - \\
\hline Diptera & & Unidentified sp. 2 & $1.39 \times 10^{-2}(0.8)$ & - \\
\hline \multirow[t]{3}{*}{ Lepidoptera } & & Unidentified sp. 3 & $0.05(2.5)$ & - \\
\hline & & Unidentified sp. 4 & - & $0.02(1.9)$ \\
\hline & & Unidentified sp. 5 & - & $0.02(1.9)$ \\
\hline \multirow[t]{5}{*}{ Hemiptera } & & Unidentified sp. 6 & $0.03(1.5)$ & - \\
\hline & & Unidentified sp. 7 & $0.04(2.2)$ & - \\
\hline & & Unidentified sp. 8 & $6.94 \times 10^{-3}(0.4)$ & - \\
\hline & & Unidentified sp. 9 & $6.94 \times 10^{-3}(0.4)$ & - \\
\hline & & Unidentified sp. 10 & $0.03(1.5)$ & - \\
\hline Passeriformes* & Nectariniidae & Cinnyris jugularis & $0.08(4.0)$ & $0.06^{\&}(8.4)$ \\
\hline
\end{tabular}

*Class Aves

${ }^{\circledR}$ The three most frequent visitors to Ixora coccinae \&The two most frequent visitors to Ruellia simplex

Previous studies by Kato et al. (2008) and Duara (2014) reported a contrast in that lepidopterans from four different families; Papilionidae, Pieridae, Nymphalidae and Lycaenidae were the main flower visitors of I. coccinae. With their long proboscis, these butterflies could collect nectar from the long tubular I. coccinae flowers and therefore visited the flowers to feed. Visits by the Asian honey bee (A. cerana) to I. coccinae flowers, however, might be for the pollen grains from the exposed position of the anthers which are located in between the corollas as hymenopterans are not equipped with suitable mouthpart to extract the nectar from the long small tubular flowers. Pollen grains are known to be consumed for 
their protein content by the nectar feeding bats, Syconycteris australis (Law 1992a, 1992b).

Ruellia simplex was previously reported to be pollinated by the giant tropical bee, Apis dorsata which was also the first record of pollination by $A$. dorsata on $R$. simplex in Thailand (Hawkeswood \& Sommung, 2016). The study stated that no other flower visitor, other than the giant bee, was present at the $R$. simplex flowers planted in a clump of about 100 plants, and therefore concluded that the giant bee was the only pollinator for the plant in that study area. Observation by Faria and Araujo (2010) on other species in Genus Ruellia (Ruellia angustifolia) reported that hummingbirds (the nectar-feeding birds) were the only visitors to the flowers. The long bills of these hummingbirds permit accessibility to the nectar of this long corolla flower and making regular visits to the flower increased their potential role as pollinators to the flower. Trip and Manos (2008) reported the transition between bee and bird pollinated species in Genus Ruellia, due to the lack of their main pollinator group which could lead to the shift in pollination mode of the plant species.

The hymenopteran and lepidopteran insects are among the most common flower visitors which contribute to pollination of the plants (Proctor \& Yeo, 2009; Willmer, 2011; Rathnayake $\&$ Wijetunga, 2016). Pollination by these insect flower visitors particularly bees has long been highlighted due to their economic importance in crop production (Potts et al., 2010; Nicholls \& Altieri, 2013; Putra et al., 2014). The longtongued bees in the genera Apis, Heterotrigona and Xylocopa (Michener, 2000) are known to extract nectar from flowers with long corolla tube, collecting and transferring pollen grains while foraging on the flowers and therefore, act as pollinating agents to the flowers they visit. When compared to insects, many flower-visiting birds inflict more damage on the flowers rather than contributing towards pollination (Willmer, 2011). Approximately 110 bird species from the family Nectariinidae (sunbirds and flower peckers) have been recorded as being involved in pollination, although not many details of their functions as pollinating agents can be found particularly in the Southeast Asian region.

Observations of foraging behaviour were conducted for the three main flower visitors of I. coccinae namely A. cerana (nine visits), $H$. itama (35 visits) and Xylocopa confusa (two visits) only (Figure 3). For R. simplex, only $A$. cerana and $C$. jugularis (Figure 4) were observed on 11 and 10 visits respectively. All the four insect visitors were found to land for foraging at the flowers. Landing on flower petals for feeding is a common foraging behaviour of insects as reported by Sarkar et al. (2014). In the study, they observed visitations to common ornamental plants (sunflower, Petunia and Buganvilia) which explained their role as pollen vectors and potential pollinating agents by contacting the flower parts. Although individual flower of $I$. coccinae is small, usually more than 10 flowers were densely packed in a rounded cluster of 5-13 cm (Duara, 2014) which allows the landing by these small insects on the flower cluster.

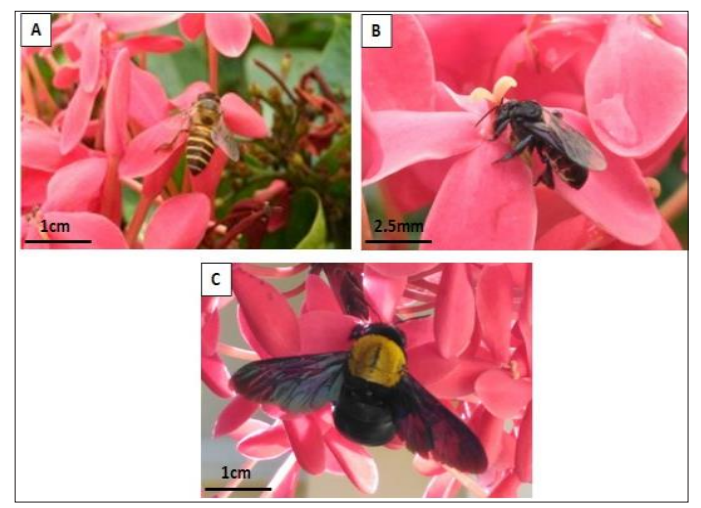

Figure 3: The landing feeding behaviour of the three main visitors of Ixora sp., A) Apis cerana, B) Heterotrigona itama, C) Xylocopa confusa 

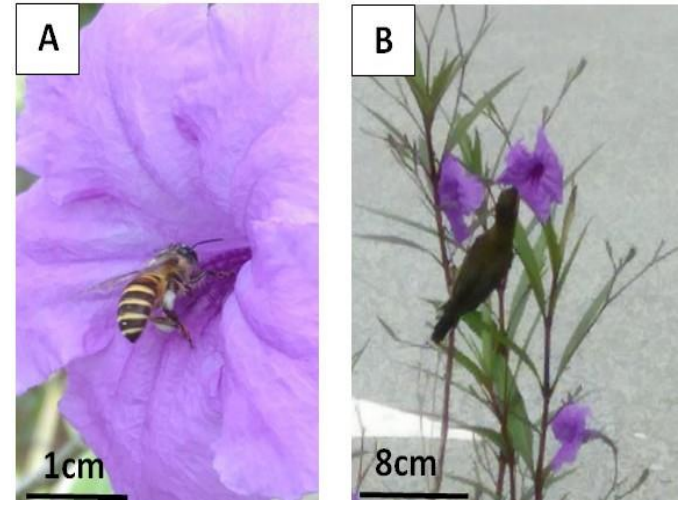

Figure 4: The two main visitors of Ruellia simplex.A) Apis cerana lands on the flower B) Cinnyris jugularis lands on the branch instead of the flower to collect nectar

For $R$. simplex, all the insect individuals were also observed to land on the flowers to feed, while $C$. jugularis were recorded to both hovering $(20 \%)$ and landing $(80 \%)$ for feeding at flowers. According to Pyke (1981), nectarfeeding birds employ hovering or landing mode of feeding depending on the energy gained from the flower they feed on. As for C. jugularis, hovering while feeding might require more energy due to its large body size as compared to the energy gained from the nectar collected from $R$. simplex flowers, therefore landing is preferable. As compared to insect visitors however, this bird landed on the branch instead of flowers and collected nectar by inserting their long bill into the flowers.

For the time spent at the flowers (Table 2), $X$. confusa spent the longest time at $I$. coccinae with the mean $( \pm \mathrm{SD})$ of $24.50 \pm 20.51 \mathrm{sec}$, followed by $H$. itama $(22.83 \pm 23.33 \mathrm{sec})$ and A. cerana $(10.11 \pm 7.61 \mathrm{sec})$. However, the time spent was not significantly different between the three visitors (Kruskal-Wallis test, $H=1.323$, $\mathrm{df}=2, \mathrm{p}=0.055)$. For $R$. simplex, A. cerana recorded significantly longer time spent at the flowers (Mann-Whitney test, $U=17.355, \mathrm{p}<$ $0.001)$ with $10.09 \pm 4.04$ sec. as compared to $2.90 \pm 0.99$ sec. recorded by $C$. jugularis.

Table 2: Time spent at the flowers (Mean \pm SD sec) of the main visitors of each flower species. Numbers in parentheses indicate range and $\mathrm{n}$ indicates the number of observations

\begin{tabular}{lcc}
\hline Visitor species & Ixora coccinae $^{*}$ & Ruellia simplex $^{* *}$ \\
\hline Apis cerana & $10.11 \pm 7.61(2-28), \mathrm{n}=9$ & $10.09 \pm 4.04(6-21), \mathrm{n}=1 \mathrm{I}$ \\
$\begin{array}{l}\text { Heterotrigona } \\
\text { itama }\end{array}$ & $22.83 \pm 23.33(3-135), \mathrm{n}=35$ & - \\
Xylocopa confusa & $24.50 \pm 20.51(10-39), \mathrm{n}=2$ & - \\
Cinnyris jugularis & - & $2.90 \pm 0.99(2-5), \mathrm{n}=10$ \\
\hline
\end{tabular}

*Not significant at $\mathrm{p}=0.05$

${ }^{* *}$ Significant at $\mathrm{p}=0.001$

According to Silva et al. (2010), variation in time spent at the flowers is due to the availability of floral reward ie. nectar and pollen grains. Manetas and Petropoulou (2000) concluded that the amount of nectar could positively affect the duration of visits thus increase the pollination success of the flowers. This finding, however, disagrees with Putra et al. (2014) in which they reported larger sized honey bee $(A$. cerana) spent less time at the flowers of pepper
(Capsicum annum) as compared to stingless bee (T. laeviceps). Both bees showed an equal contribution to the pollination success to the flowers they visited, and they concluded that larger body size might compensate for their shorter visitation time. Larger sized pollinators, for example, carry larger pollen loads and can travel a long distance to promote crosspollination (eg. Horner et al. 1998; MolinaFreaner et al. 2003). 


\section{Conclusion}

According to their visitation frequency and foraging mode at the flowers, A. cerana, $H$. itama and $X$. confusa were the most important pollinating agents of $I$. coccinae. Not only did they showed high visitation rate, but these three insect species foraged by landing and spending more than $10 \mathrm{sec}$. to forage at the flowers. For $R$. simplex the most important pollinating agent was A. Cerana, which showed landing behaviour in every visit and spent a significantly longer time to forage at the flowers then the sunbird (Cinnyris jugularis). The sunbird, on the other hand, not only spent about $3 \mathrm{sec}$. at the flowers, but occasionally showed hovering feeding mode. Their vital role as pollinating agent to $R$. simplex nevertheless could be from their larger body size as compared to other smaller sized insect visitors to the flowers.

\section{Acknowledgements}

We would like to thank the School of Marine and Environmental Sciences for the equipment used and logistic support while conducting this research, Dr Norasmah Basari for her help in identification of the insects, and Prof. Dato' Dr. Mohd Tajuddin Abdullah for his constructive comments on this article.

\section{References}

Bloom, M. (1976). Evolution in the genus Ruellia (Acanthaceae): A discussion based on the floral flavonoids. American Journal of Botany, 36, 399-405.

Cronk, Q., \& Ojeda, I. (2008). Bird-pollinated flowers in an evolutionary and molecular context. Journal of Experimental Botany, 59 (4), 715-727.

De Block, P. (1998). The African species of Ixora (Rubiaceae-Pavetteae). Opera Botanica Belgica, 9, 1-218.

Dobson, H. E. M. (2006) Relationship between floral fragrance composition and type of pollinator. In: Dudareva, N. \& Pichersky, E. (Eds.), Biology of Floral Scent. Taylor \& Francis, Florida. pp. 147-198.
Dreisig, H. (1997). Why do some nectar foragers perch and others hover while probing flowers? Evolutionary Ecology, 11(5), 543555.

Duara, P. (2014). Effectiveness and importance of butterflies as pollinators to the flowers of Ixora coccinea. International Journal of Research Studies in Biosciences, 2(11), 7174.

Faria, R. R., \& Araujo, A. C. (2010). Pollination ecology of Ruellia angustiflora (Ness) Lindau ex Rambo (Acanthaceae) in the Serra da Bodoquena, Mato Grosso do Sul, Brazil. Flora Morphology, Distribution, Functional Ecology of Plants, 205(2), 106 - 111.

Fleming, T. H., \& Sosa, V. J. (1994). Effects of nectarivorous and frugivorous mammals on reproductive success of plants. Journal of Mammalogy, 75, 845-851.

Glover, B. J. (2007). Understanding Flowers and Flowering: An Integrated Approach. Oxford University Press, Oxford. 227 pp.

Hawkeswood, T. J., \& Sommung, B. (2016). Pollination of Ruellia simplex C. Wright (Acanthaceae) by the Giant Tropical Bee, Apis dorsata (Fabr., 1793) (Hymenoptera: Apidae) in Bangkok, Thailand. Calodema, 438, 1-5.

Horner, M. A., Fleming, T. H., \& Sahley, C. T. (1998). Foraging behaviour and energetics of a nectar-feeding bat, Leptonycteris curasoae (Chiroptera: Phyllostomidae). Journal of Zoology, 244, 575-586.

Inouye, D. W. (1980). The terminology of floral larceny. Ecology, 61, 1251-1253.

Jedrzejewska-Szmek, K., \& Zych, M. (2013) Flower-visitor and pollen transport networks in a large city: Structure and properties. Arthropod-Plant Interactions, 7, 503-516.

Johnson, C. M., \& Pauw, A. (2014) Adaptation for rodent pollination in Leucospermum arenarium (Proteaceae) despite rapid pollen loss during grooming. Annals of Botany, 113, 931-938. 
Kato, M., Kosaka, Y., Kawakita, A., Okuyama, Y., Kobayashi, C., Phimminith, T. \& Thongphan, D. (2008). Plant-pollinator interactions in tropical monsoon forest in Southeast Asia. American Journal of Botany, 95(11), 1375-1394.

Law, B. S. (1992a). Physiological factors affecting pollen use by Queensland blossom bats (Syconycteris australis). Functional Ecology, 6, 257-264.

Law, B. S. (1992b). The maintenance nitrogen requirements of the Queensland blossom bat (Syconycteris australis) on a sugar/ pollen diet: Is nitrogen a limiting resource? Physiological Zoology, 65, 634-648.

Manetas, Y., \& Petropoulou, Y. (2000). Nectar amount, pollinator visit duration and pollination success in the Mediterranean Shrub Cistus creticus. Annals of Botany, 86, 815-820.

Michener, C. D. (2000). Bees of the World. Johns Hopkins University Press, Baltimore. 913 pp.

Molina-Freaner, F., Cervantes-Salas, M., Morales-Romero, D., Buchmann, S., \& Fleming, T. F., (2003). Does the pollinator abundance hypothesis explain geographic variation in the breeding system of Pachycereus pringlei? International Journal of Plant Sciences, 164, 383-393.

Mouly, A., Razafimandimbison, S. G., Khodabandeh, A. \& Bremer, B. (2009). Phylogeny and classification of the speciesrich Pantropical showy Genus Ixora (Rubiaceae-Ixoreae) with indications of geographical monophyletic units and hybrids. American Journal of Botany, 96(3), 686-706.

Nicholls, C. I. \& Altieri, M. A. (2013). Plant biodiversity enhances bees and other insect pollinators in agroecosystems. A review. Agronomy for Sustainable Development, 33, 257-74.
Nilsson, L. A., Rabakonandrianina, E., Pettersson, B., \& Ranaivo, J. (1990). "Ixoroid" secondary pollen presentation and pollination by small moths in the Malagasy treelet Ixora platythyrsa (Rubiaceae). Plant Systematics and Evolution, 170, 161-175

Olesen, J. M., \& Valido, A. (2003) Lizards as pollinators and seed dispersers: An island phenomenon. Trends in Ecology \& Evolution, 18 (4), 177-181.

Ollerton, J., Rech, A. R., Waser, N. M., \& Price, M. V. (2015). Using the literature to test pollination syndromes-some methodological cautions. Journal of Pollination Ecology, 16 (17), 119 - 125.

Potts, S. G., Biesmeijer, J. C., Kremen, C., Neumann, P., Schweiger, O., \& Kunin, W.E. (2010). Global pollinator declines: Trends, impacts and drivers. Trends in Ecology and Evolution, 25, 345-353.

Proctor, M. C. F., \& Yeo, P. (2009). The Pollination of Flowers. HarperCollins Publishers Limited, New York. 386 pp.

Putra, R. E., Permana, A. D., \& Kinasih, I. (2014). Application of Asiatic honey bees (Apis cerana) and stingless bees (Trigona laeviceps) as pollinator agents of hot pepper (Capsicum annuum L.) at local Indonesia farm system. Psyche: A Journal of Entomology, 2014, doi.org/10.1155/2014/687979.

Pyke, G. H. (1981). Why hummingbirds hover and honeyeaters perch. Animal Behaviour, 29 (3), 861-867.

Rajaseger, G., Tan, H. T. W., Turner, I. M., \& Kumar, P. P. (1997). Analysis of genetic diversity among Ixora cultivars (Rubiaceae) using random amplified polymorphic DNA. Annals of Botany, 80, 355-361.

Rathnayake, D. G.R. M. M. K. \& Wijetunga, W. M. G. A. S. T. B. (2016). Species composition and visiting frequencies of flower visitors of Chromolaena odorata in a dry zone forest patch in Sri Lanka. Psyche: A Journal of Entomology, 2016, doi.org/10.1155/2016/8746251. 
Rech, A. D., Dalsgaard, B., Sandel, B., Sonne, J., Svenning, J-C., Holmes. N., \& Ollerton, J. (2016). The macroecology of animal versus wind pollination: Ecological factors are more important than historical climate stability. Plant Ecology \& Diversity, 9 (3), 253-262.

Regal, P. J. (1982) Pollination by wind and animals: Ecology of geographic patterns. Annual Review of Ecology and Systematics, 13, 497-524.

Sarkar, S., Nandy, A., \& Talapatra, S.N. (2014). Ethological study of flower visiting insects in two parks, Kolkata, India. International Letters of Natural Sciences, 12(1), 41-54.

Silva, F. O., Kevan, S. D., Roque, N., Viana, B. F., \& Kevan, P. G. (2010). Records on floral biology and visitors of Jacquemontia montana (Moric.) Meisn (Convolvulaceae) in Mucugê, Bahia. Brazilian Journal of Biology, 70 (3), 671-676.
Slaa, E. J., Chaves, L. S., Malagodi-Braga, K. S., \& Hofstede, F. E. (2006). Stingless bees in applied pollination: practice and perspectives. Apidologie, 37 (2), 293 - 315.

Stein, K., \& Hensen, I. (2011). Potential pollinators and robbers: A study of the floral visitors of Heliconia Angusta (Heliconiaceae) and their behaviour. Journal of Pollination Ecology, 4 (6), 3947.

Tripp, E. A., \& Manos, P. S. (2008). Is floral specialization an evolutionary dead-end? Pollination system transitions in Ruellia (Acanthaceae). Evolution, 62, 1712-1737.

Wasshausen, D.C. \& Wood, J.R.I. (2203). Note on the Genus Ruellia (Acanthaceae) in Bolivia, Peru and Brazil. Proceedings of Biological Society of Washington, 116, 263 274.

Willmer, P. (2011). Pollination and Floral Ecology. Princeton University Press, New Jersey. 778 pp. 
